\title{
第54回 日本視能矯正学会
}

\section{一般講演}

\section{エゴグラムからみた視能矯正專攻学生の成長過程 -1 年次と 4 年次のエゴグラムの比較—}

難波 哲子 1, 2) - 小林 泰子 ${ }^{1,2}$ 2) - 山下 力 ${ }^{1,2)}$ - 田淵 昭雄 ${ }^{1)}$

1) 川崎医療福祉大学 医療技術学部 感覚矯正学科

2) 川崎医科大学 眼科学教室

\section{Growth of Orthoptic Students After a 4-year Course Evaluated by Egogram}

-Comparison Between the First -and Fourth-Year Results of Egogram

\author{
Tetsuko Namba ${ }^{1), 2)}$, Yasuko Kobayashi ${ }^{1,2)}$, \\ Tsutomu Yamashita ${ }^{1), 2)}$, Akio Tabuchi ${ }^{11}$ \\ ${ }^{1)}$ Department of Sensory Science, Faculty of Health Science and Technology, Kawasaki University \\ of Medical Welfare \\ ${ }^{2)}$ Department of Ophthalmology, Kawasaki Medical School
}

要 約

【目的】同一学生の 1 年次と 4 年次の自我状態の変化を検討する。

【対象および方法】調查対象は平成 20 年度〜平成 22 年度視能矯正専攻入学生のうち 89 名（女性 83 名、男性 6 名)、平均年齢は 1 年次が 18.4 歳、 4 年次が 21.3 歳であった。調查方法は、新版東大式工 ゴグラム II ${ }^{\otimes}(\mathrm{TEG})$ を用いて、 1 年次は 5 月、 4 年次は実習終了後の 7 月に説明後同意の得られた 学生に集団で行なった。

【結果】 TEGの各項目尺度別平均值は、1年次、4年次の順に、支配的親（CP）は10.1、9.9、養 育的親（NP）は14.6、15.6、成人（A）は8.9、9.7、自由な子ども（FC）は12.7、12.8、順応し

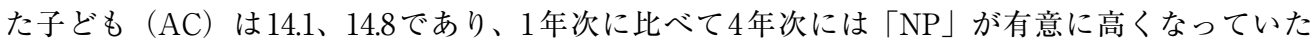

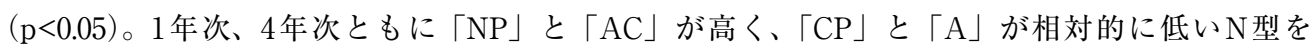
示した。基本的構え（OKグラム）では、1年次、 4 年次ともに自己否定・他者肯定型が多かった。 TEG パターン分類で最も多いのは、1年次では AC 優位型が 25 名 $(28.1 \%) 、 4$ 年次ではN 型 I が 18 名 (20.2\%) であった。

【結論】視能矯正専攻における態度育成の教育では、1年次からもっている、医療職に必要とされる

別冊請求先（† 701-0193）岡山県倉敷市松島 288

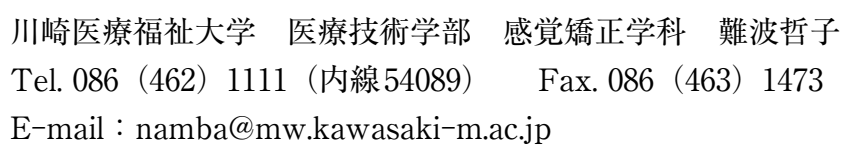

Key words：エゴグラム、OKグラム、視能訓練士教育、自我状態、性格特性

Egogram, OKgram, orthoptic education, ego state, personality trait 


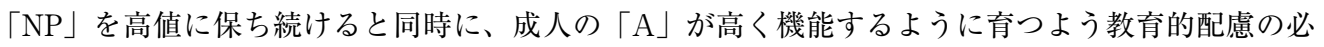
要性が示唆された。

\section{Abstract}

【Purpose】 A group of orthoptic college students were evaluated at the first and fourth years to investigate changes in their ego state.

【Subjects and Methods】 Subjects were 89 college students ( 83 females and 6 males) who enrolled in the orthoptic course between 2008 and 2010. The mean ages were 18.4 (first year) and 21.3 (fourth year). Using the Tokyo University Egogram II $^{\circledast}$ (TEG, New Version II), the subjects were evaluated in May of the freshman year and in July of the senior year after they had completed the training program. All the subjects were evaluated as a group and informed consents were obtained.

【Results】 The average scores (in the order of 1st and 4th years) of the five scales of TEG II were: 10.1 and 9.9 for Critical Parent (CP), 14.6 and 15.6 for Nurturing Parent (NP), 8.9 and 9.7 for Adult (A), 12.7 and 12.8 for Free Child (FC), and 14.1 and 14.8 for Adapted Child (AC). The "NP" score of the fourth year was significantly higher than that of the first year $(P<0.05)$. While the "NP" and "AC" scores were high in both the first and fourth years, the "CP" and "A" scores were relatively low and this indicated a "N" type. As for the basic attitude (OK gram), self-denial and other-affirmation types were common in both the first and fourth years. The results of the TEG pattern classification showed that $\mathrm{AC}$ dominant type and $\mathrm{N}$ type I were the most common types for the first year (25 students, 28.1\%) and the fourth year (18 students, 20.2\%), respectively.

【Conclusion】 To cultivate a nurturing attitude in orthoptic students, special considerations should be given to the college education for the students to retain a high "NP" score, which is high in the freshman year and essential for the medical profession, and to achieve a higher "A" score at the same time.

\section{I 。緒言}

視能訓練士教育では、基本的知識や技術 - 技 能に加えて、医療人としての人間性や倫理観、 責任感、コミュニケーション能力などの情意領 域の教育が重要視され、講義や演習をはじめ、 学内実習㧍よび臨地実習で多くの時間が費やさ れている ${ }^{1)}$ 。大学の 4 年間は、学生にとって新 たな基礎教育と専門教育を身につけ、自己成長 のための貴重な時期といえる。その過程の中

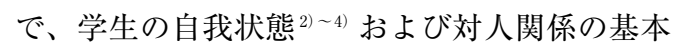
的構え ${ }^{5)}$. $)$ がどのように変化するかを把握する ことは、医療人の養成課程、および青年期の成 長過程において大切である。また、学生教育の 評価あるいは学生のメンタルヘルスの評価7), 8) においても意義がある。私どもは、視能訓練士 教育の領域において、新版東大式エゴグラム II ${ }^{\circledR}$ を活用し、臨地実習の指導者評価および学生に
よる自己評価の関係、学生の自我状態と対人関 係の心構えの変化を検討して、学生自身の自己 理解などに役立ててきた ${ }^{9)}$ 。

今回、同一学生の 1 年次と臨地実習終了後の 4 年次の自我状態と基本的構えの状態掞よびそ の変化を捉え検討したので報告する。

\section{II. 対象及び方法}

\section{1. 調査対象}

対象は、平成 20 年度〜平成 22 年度入学の川 崎医療福祉大学医療技術学部感覚矯正学科視能 矯正専攻学生のうち 89 名（女性 83 名、男性 6 名)、年齢は 1 年次が 18.4 歳 \pm 0.5 歳（18歳～ 20 歳)、 4 年次が 21.3 歳 \pm 0.5 歳 (21歳〜 23 歳) で あった。

\section{2. 調查方法}

調查方法は、新版東大式エゴグラム II ${ }^{\circledR}$ 
（Tokyo University egogram：TEG）を用いた。 調查時期は、 1 年次では視能矯正専門科目の第 1 回講義後の 5 月、 4 年次では視能臨地実習終了 後の 7 月に説明後同意の得られた学生に集団で 行い回収した。

1）新版東大式エゴグラム ${ }^{\circledR} \mathrm{II} \quad(\mathrm{TEG})^{4)}$

東大式エゴグラムは、米国の精神科医エリッ ク・バーン（Eric Berne）の交流分析理論に 基づき、弟子のジャック・デュッセイ（Jack Dusay）が自我状態を量的に表現するためにエ ゴグラムを考案して、それをもとに東京大学 医学部心療内科で多変量解析により開発した 質問紙法心理検査である。TEG は自我状態に 気づき、自己分析するためのツールであり、自 己成長を促したり、対人関係における行動様 式を考える上で活用される。TEGは、自己の 5つの自我状態、支配的親 (Critical Parent ; $\mathrm{CP}) 、$ 養育的親 (Nurturing Parent; NP)、成 人 (Adult；A)、自由な子ども (Free Child； FC)、順応した子ども (Adapted Child；AC)
を視覚的に把握し、客観的に自己分析する人格 検査である（図1）。すなわち、(1)約50の質問 からなる自己記入式の質問紙に、「はい」：2点、

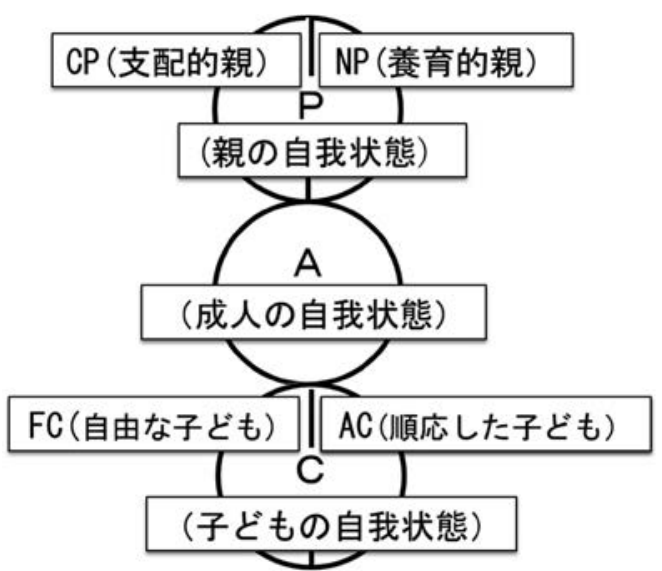

図 1 東大式エゴグラム（TEG）の5つの自我状態 $\mathrm{P}$ :親の自我状態、 $\mathrm{A}$ : 大人の自我状態、C: 子ど もの自我状態、 $\mathrm{CP}$ :支配的親、 NP: 養育的親、 $\mathrm{A}$ :成人、FC:自由な子ども、 $\mathrm{AC}$ : 順応した子ど もを示す。

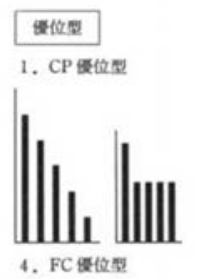

4. FC 数位震
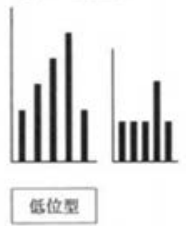

6. $\mathrm{CP}$ 的位柴

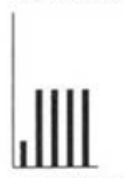

9. FC 酶位量

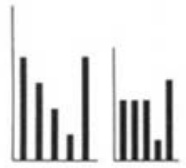

2. NP S位䔩

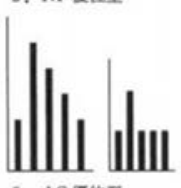

5. AC 優位整

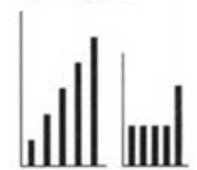

7. NP 钻位臬

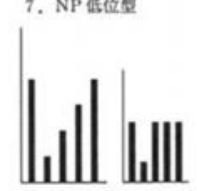

10. $\mathrm{AC}$ 结位果

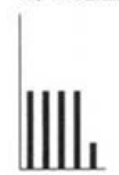

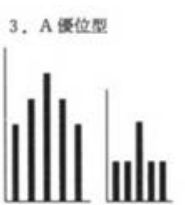

8. A 佂位策

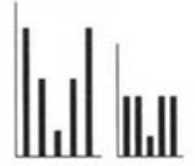

15. M9

16. W⿻
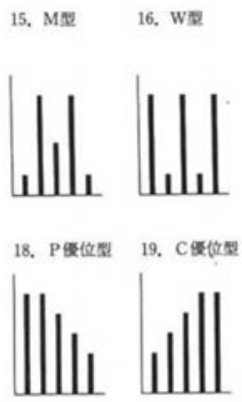

13. N 5
12. U⿻上丨

III II III III
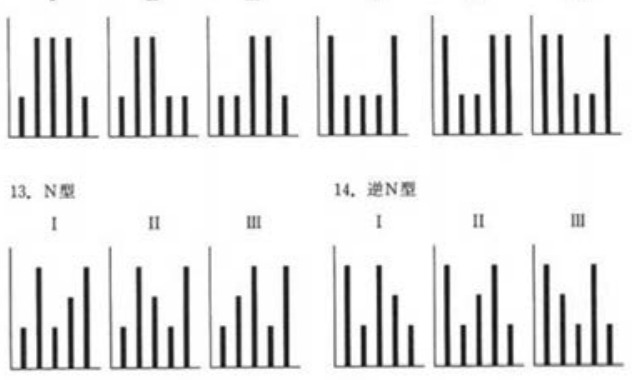

資料1 TEGパターン分類

(野村 忍：TEGパターン分類の作業手順. 東京大学医学部心療内科 TEG研究会編 : 新版 TEG II 解説と エゴグラム・パターン. $50-51$, 金子書房, 東京, 2006. を引用) 
$\lceil$ 「゙ちらでもない」：1点「「いいえ」：0点とする 3 件法で回答する。(2)得点を尺度ごとに20点満 点で合計点数化して棒グラフを作成し、パター ン化する。TEG検査により得られた尺度得点 をもとに、東京大学医学部心療内科 TEG研究 会によるTEGパターン分類の手順にしたがい、 19 パターン 29 型に分類する ${ }^{4)}($ 資料1)。(3)パ ターンにより性格・行動のあり方を測定し自己 分析する。また、各尺度得点をスケールの同数 字の位置にプロットする。プロット同士を線で 結び、描かれた折れ線グラフより TEGエゴグ ラム曲線を作成する。なお、エゴグラムの各要 素については表 3 の参考付表の通りである ${ }^{4}$ (表 $3)$ 。

\section{2） TEGの5つの尺度の読み方}

TEGは5つの尺度の得点が高い・低いによっ て解釈して、 $\mathrm{CP}$ と $\mathrm{NP} 、 \mathrm{FC}$ と $\mathrm{AC}$ との関係など 他の尺度との相対的関連を理解することが重要 である。また、それぞれの尺度がその人の行動 パターンの主役を担っていると考えられる。し たがって、実際の読み取り方は、一番高い尺度 はどれか、次に高い尺度はどれかというように 順番をつける。そして、エゴグラムパターンの 一覧表を見て、最も高いパターンを同定する。

3）対人関係の基本的構え

基本的構え（OKグラム）では、エゴグラム に扔ける下位尺度得点間の比較基準を設けて4 つの類型に分けた ${ }^{2)}{ }^{5}$. 7)。4つの類型とは、自 分自身が自己及び他者を肯定ないし否定する という観点から、“I'm OK - I'm Not OK”軸 と “You're OK - You're Not OK” 軸という2軸 が交差してできる4象限に位置するエゴグラム

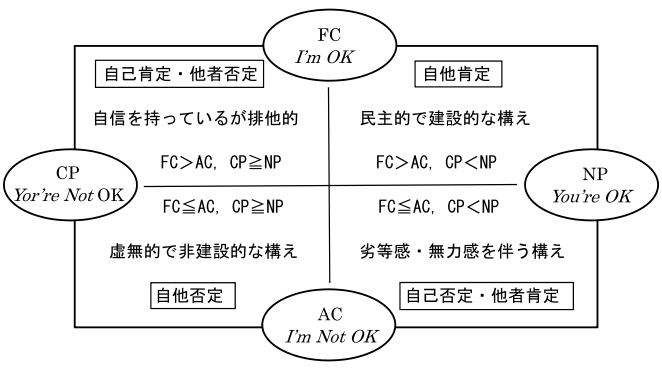

図 2 基本的構えの 4 種類

(スチュアート・ジョインズ ${ }^{2)}$ が表したものと 新里他 ${ }^{5)}$ を参考にして改編)

不等号は、2軸を構成する尺度の優劣関係を表す。

個人特性である。基本的構えの 4 類型は、 2 軸 4 象限の第 1 象限である自己肯定・他者肯定型 (I'm OK：You're OK、自他肯定型)、第2象限 の自己肯定 ·他者否定型 (I'm OK : You're Not $\mathrm{OK}$ )、第3象限の自己否定・他者肯定型（I'm Not OK : You're OK)、第4象限の自己否定. 他者否定型（I'm Not OK：You're Not OK、自 他否定型）として表される（図2）。それぞれの 基本的構えの特徵として、自他肯定型は自他の 尊重による民主的で前向きな構え、自他肯定・ 他者否定型は自己愛的で排他的な構え、自己否 定・他者肯定型は自己犠牲的で劣等感を伴う構 え、自他否定型は虚無的で不毛な構えが想定さ れる 2) 6) .7)。

3. 分析方法

統計処理は、Wilcoxonの符号付順位和検定を 用いて、有意水準 $5 \%$ 未満を有意差ありとした。

4. 倫理的配慮

検査に先立って、学生に自我状態を検討し、 今後の実習指導等の基礎資料としたい旨を説明

表3 参考付表 エゴグラムの各要素

\footnotetext{
CP ; 目標が高く理想を追求し、自分にも他人にも厳しい。基本的には他者否定の構えを有する。 $\mathrm{NP}$; 他人をいたわり、親切で寛容な態度を示す。基本的には他者肯定の構えを示す。

A ; 事実に基づき、物事を客観的かつ論理的に理解し判断しようとする。他の自我状態の調整役 でもある。

$\mathrm{FC}$; 感情や欲求を自由に表現する自我状態である。本能的、自己中心的で好奇心、直感、創造力 と関連性がある。基本的には自己肯定の構えを有する。

$\mathrm{AC}$; 周囲に適応していく従順な自我状態である。親の躾や教育の影響を多分に受けている。基本 的には自己否定の構えを有する。

(野村 忍 : エゴグラムの解釈. 東京大学医学部心療内科 TEG 研究会編 : 新版 TEG II 解説とエゴ グラム・パターン. 19-23, 金子書房, 東京, 2006。を引用)
} 
した。趣旨説明とともに調查協力を依頼し、同 意と協力の得られた学生から回答を記入した用 紙を回収した。結果については集団を対象とし た量的分析を行なうため、個人データとして取 り扱わないこと、目的以外には使用しないこ となど、個人情報保護への配慮を充分に説明し た。エゴグラム変化の結果は、個人票を作成し て学生に返却することを伝え、記名式を採用し た。なお、本研究は、川崎医療福祉大学倫理審 査委員会で承認（承認番号 397）を得たうえで 行なった。

\section{III. 結果}

1. 1 年次と 4 年次の TEG の尺度別平均值の比較 表1に示す通り、TEGの各項目尺度得点の 平均值 \pm 標準偏差は、 1 年次、 4 年次の順に、 $\lceil\mathrm{NP}\rfloor\lceil\mathrm{AC}\rfloor\lceil\mathrm{FC}\rfloor\lceil\mathrm{CP}\rfloor 、 \mathrm{~A}\rfloor$ の順に高 かった（表1）。1年次に比べて 4 年次で平均值 が増加した項目は、NP、A、FC、ACであり、 平均值が減少した項目はCPであった。TEGの 各項目尺度得点の平均值では、 1 年次に比べて 4 年次の NPは、有意に高くなっていた（ $\mathrm{p}<0.05 ）$ (図3)。しかし、NP以外の項目では有意差はな かった。TEGパターンは、1年次、4年次とも にNPと ACが同程度に高く、CP と A が相対的 に低い N型を示していた。

2. 対人関係の基本的構えの変化

1 年次と 4 年次における対人関係の基本的構 えは、自他肯定、自己肯定・他者否定、自己否 定・他者肯定、自他否定の 4つの型に分類した 結果、図4の通りであった（図4）。基本的構え の人数は、 1 年次、 4 年次の順に、自他肯定型 では 14 名 (15.7\%)、18名 (20.2\%)、自己肯定・ 他者否定型では12名 (13.5\%)、6名 (6.7\%)、 自己否定・他者肯定型では51名 (57.3\%)、57 名 $(64.1 \%) 、$ 自他否定型では 12 名 (13.5\%)、8

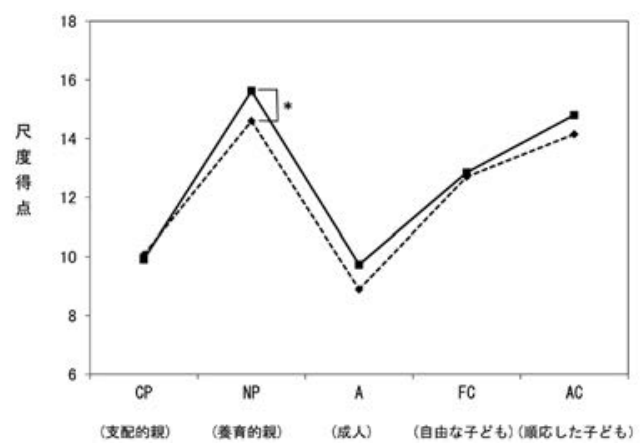

図 31 年次と 4 年次の自我状態の比較 $-\cdots-1$ 年次、— 4 年次、 $\mathrm{n}=89$ $* \mathrm{p}<0.05$ を示す。Wilcoxonの符号付き順位和 検定

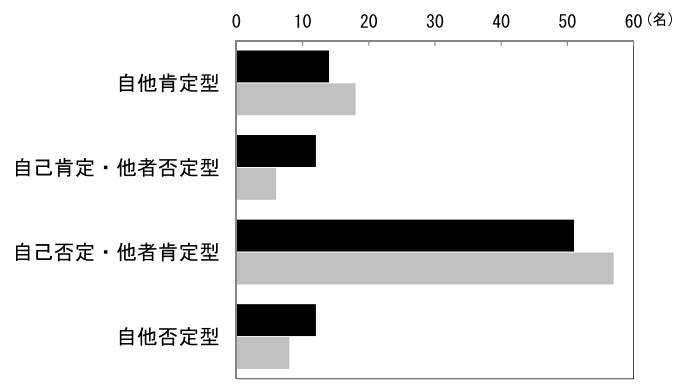

図 4 基本的構えの人数

は 1 年次、は 4 年次を示す。 1 年次、 4 年 次ともに自己否定・他者否定型が最も多い。

名（9.0\%）であった。 1 年次、 4 年次ともに自己 否定・他者肯定型が最も多く、1年次よりも 4 年次には更に増加した。4年次には他者を肯定 する人数が多くなり、反対に他者を否定する人 数は減少した。

3. 1 年次と 4 年次の TEG パターン分類の比較 TEGパターンは、19パターン29型に分類 した後、該当する人数を集計して、1年次と 4 年次の差の大きい順に並べた（表2）。1年次 の TEGパターンでは、AC優位型、NP優位 型の順で多く、全体の 39 名（43.8\%）を占め た。次いで、N型 I、FC優位型が多く、この

表1 TEG の尺度別平均值

\begin{tabular}{rrrcccc}
\hline & $\mathrm{CP}$ & $\mathrm{NP}$ & $\mathrm{A}$ & $\mathrm{FC}$ & $\mathrm{AC}$ & 合計 \\
\hline 1 年次 & $10.1 \pm 4.3$ & $14.6 \pm 3.9$ & $8.9 \pm 4.8$ & $12.7 \pm 4.5$ & $14.1 \pm 5.0$ & $60.3 \pm 10.8$ \\
4 年次 & $9.9 \pm 4.0$ & $15.6 \pm 3.8$ & $9.7 \pm 4.6$ & $12.8 \pm 4.8$ & $14.8 \pm 5.0$ & $62.9 \pm 11.9$ \\
\hline
\end{tabular}


表 $2 \quad 1$ 年次と 4 年次のパターン分類比較

\begin{tabular}{|c|c|c|c|c|c|c|c|}
\hline \multirow[b]{3}{*}{1} & \multirow{2}{*}{ パターン } & \multicolumn{2}{|c|}{1 年次 } & \multicolumn{2}{|c|}{4 年次 } & \multicolumn{2}{|c|}{1 年次と 4 年次の差 } \\
\hline & & \multirow{2}{*}{$\frac{\text { 人数 (名) }}{10}$} & \multirow{2}{*}{$\begin{array}{c}\% \\
11.2 \\
\end{array}$} & \multirow{2}{*}{$\frac{\text { 人数 (名) }}{18}$} & \multirow{2}{*}{$\frac{\%}{20.2}$} & \multirow{2}{*}{$\frac{\text { 人数 (名) }}{8}$} & \multirow{2}{*}{\begin{tabular}{|c|}
$\%$ \\
9.0
\end{tabular}} \\
\hline & 型 I & & & & & & \\
\hline 2 & $\mathrm{~N} \quad$ 型 $\quad$ III & 2 & 2.2 & 10 & 11.2 & 8 & 9.0 \\
\hline 3 & $\mathrm{~N} \quad$ 型 $\quad \mathrm{II}$ & 4 & 4.5 & 10 & 11.2 & 6 & 6.7 \\
\hline 4 & 型 & 3 & 3. 4 & 5 & 5.6 & 2 & 2.2 \\
\hline 5 & A 低 位 & 3 & 3.4 & 5 & 5.6 & 2 & 2.2 \\
\hline 6 & U 型 I & 0 & 0.0 & 2 & 2.2 & 2 & 2.2 \\
\hline 7 & C P 低 位 & 1 & 1.1 & 2 & 2.2 & 1 & 1.1 \\
\hline 8 & 台 形型 I & 0 & 0.0 & 1 & 1.1 & 1 & 1.1 \\
\hline 9 & U 型 III & 0 & 0.0 & 1 & 1.1 & 1 & 1.1 \\
\hline 10 & 逆 $\mathrm{N}$ 型 II & 0 & 0.0 & 1 & 1.1 & 1 & 1.1 \\
\hline 11 & $\mathrm{P}$ 優 位 & 0 & 0.0 & 1 & 1.1 & 1 & 1.1 \\
\hline 12 & W 型 & 3 & 3.4 & 3 & 3.4 & 0 & 0.0 \\
\hline 13 & 平 坦 型 I & 2 & 2.2 & 2 & 2.2 & 0 & 0.0 \\
\hline 14 & N P 低 位 & 1 & 1.1 & 1 & 1.1 & 0 & 0.0 \\
\hline 15 & A C 低 位 & 0 & 0.0 & 0 & 0.0 & 0 & 0.0 \\
\hline 16 & 台 形 型 II & 0 & 0.0 & 0 & 0.0 & 0 & 0.0 \\
\hline 17 & 台 形 型 III & 0 & 0.0 & 0 & 0.0 & 0 & 0.0 \\
\hline 18 & 平 坦 型 II & 0 & 0.0 & 0 & 0.0 & 0 & 0.0 \\
\hline 19 & 平 坦 型 III & 0 & 0.0 & 0 & 0.0 & 0 & 0.0 \\
\hline 20 & 逆 $\mathrm{N}$ 型 $\mathrm{I}$ & 3 & 3.4 & 2 & 2.2 & -1 & -1.1 \\
\hline 21 & F C 低 位 & 2 & 2.2 & 1 & 1.1 & -1 & -1.1 \\
\hline 22 & 逆 $\mathrm{N}$ 型 $\mathrm{III}$ & 2 & 2.2 & 1 & 1.1 & -1 & -1.1 \\
\hline 23 & C P 優 位 & 1 & 1.1 & 0 & 0.0 & -1 & -1.1 \\
\hline 24 & $\mathrm{U} \quad$ 型 $\quad$ II & 1 & 1.1 & 0 & 0.0 & -1 & -1.1 \\
\hline 25 & C P 優 位 & 1 & 1.1 & 0 & 0.0 & -1 & -1.1 \\
\hline 26 & A 優 位 & 4 & 4.5 & 2 & 2.2 & -2 & -2.2 \\
\hline 27 & F C 優 位 & 7 & 7.9 & 3 & 3.4 & -4 & -4.5 \\
\hline 28 & N P 優 位 & 14 & 15.7 & 6 & 6.7 & -8 & -9.0 \\
\hline 29 & $\mathrm{~A} \mathrm{C}$ 優 位 & 25 & 28.1 & 12 & 13.5 & -13 & -14.6 \\
\hline & 合 計 & 89 & 100.0 & 89 & 100.0 & 0 & 0.0 \\
\hline
\end{tabular}

4 パターンで全体の 56 名（62.9\%）を占めてい た。4年次の TEGパターンではN 型 I、AC優 位型、N型 II N N 型 III の順で多く、全体の50名 （56.1％）を占めていた。次いで、NP優位型、 $\mathrm{M}$ 型、 $\mathrm{A}$ 低位型が多く、これら 7 パターンで 66 名 $(74.0 \%)$ を占めていた。 1 年次と 4 年次の 変化の差が大きい TEGパターンは、AC優位型 $(-14.6 \%) 、 \mathrm{NP}$ 優位型 $(-9.0 \%) 、 \mathrm{~N}$ 型 I (+ $9.0 \%) 、 \mathrm{~N}$ 型 III $(+9.0 \%) 、 \mathrm{~N}$ 型 II $(+6.7 \%)$ 、 FC優位型（-4.5\%）であった。

\section{IV. 考按}

視能矯正専攻学生が、状況の変化や対人関係 を通じて自己をどのように捉え、変化してい るかを TEGによって把握し、基本的構えにつ いて検討した。その結果、TEGの特徴は、1年 次、4年次ともにNPと ACが高く、 CPとAの 低い $\mathrm{N}$ 型を示し、自我状態の著変はなかった。 $\mathrm{N}$ 型TEGの特徵は、思いやり (NP) や協調性 （AC）はあるが、専門知識を活用し価值判断す 
る・責任をとる（CP）が低く、現状を把握し 全体を統合して洞察する、事実を確かめて対応 する（A）が低い傾向を示すといわれている ${ }^{10)}$ 。 また、N型は思いやりや順応性があるものの、 他者に合わせるように自己否定・他者肯定の傾 向を示す ${ }^{11)}$ と考えられている。

$\lceil\mathrm{A} 」$ が低く「AC」の高いパターンは自己受 容感が低く、自分に自信がなく、他人に対して 心を開くことができないために不適応を感じや すいと報告されている ${ }^{12)}$ 。「A」が低位である、 あるいは実習前後で変化がみられないのは、他 の情報と組み合わせて総合的に判断すること に時間を要したり、難しいという学生が多いこ とから、科学的根拠に基づいた総合的判断が 困難なことと推察される ${ }^{13)}$ 「复」が「FC」や $\lceil A C 」 よ り$ 低い学生において、不安傾向が強 く、外的刺激による影響を受けやすくストレス を生じる可能性が高い ${ }^{10)}$ 。梅津 ${ }^{14)}$ 、武藤 ${ }^{15)}$ は、 TEGについて自他肯定を示す成長・成熟した理 想の医療職でみられる「への字型・ベル型」に 近づけるため、「NP」だけでなく、低い自我状 態「CP」、「A」、「FC」を高める教育が必要で あると述べている。

自我状態「成人、考える私：A」は、事実に 基づいて判断する、筋道をたてて考えるなどの 思考力が育成されると高まる ${ }^{10)}$ 。この自我状態 が高まっていくには、専門性に必要となる確か な知識・概念、価值づけ、役割と責任を引き受 ける・引き受けさせる、行動規範が育つ必要 があり、自我状態では「支配的親、価值づける 私：CP」が働かなければならない。「CP」は、 自他に対する支配的な厳しさを示すものであ り、理想の追求という面がある。高かった 1 年 次のCPスコアが、4年次に低下することは、教 育の影響や生活の経験により、理想と現実が近 づいたということが考えられる ${ }^{16)}$ 。一方、「CP」 は自他に対する批判的な厳しさを示すものであ るため、「価值づける私」を高めることが望ま しい。

パターン分類では、1年次に他者に合わせ る自我状態 $\mathrm{AC}$ 優位型がみられたが、4年次で は思いやる自我状態「NP」を優位としたエゴ グラムの傾向に変化した。日本人の平均的プ
ロフィールあるいは健全なプロフィールは、

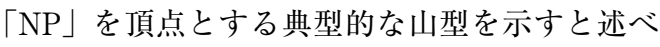
ている ${ }^{17)}$ 。今後、視能矯正専攻学生の自我状態 は、養育的親の自我状態「NP」を頂点とする 「への字型」に近づけていく教育が必要である。

稲葉ら ${ }^{18)}$ は高不安群のエゴグラムはN 型で A は低い傾向にあるといい、外的刺激による影 響を受け易くストレスを生じる可能性が高い と報告している。本調査では、「A」が「FC」・ $\lceil A C 」 よ り$ 低值であることから、実際に即した 対応がとりにくく、さらに、緊張・不安傾向に なりやすい。したがって、予期情報の提供と時 期を得た対処へのサポート等、「A」が機能しや すい配慮が 1 年次の当初から重要となることが 示唆された。

実習における達成感を通してさらなる自己啓 発への動機付けができれば、責任感、思慮深 さ、思いやりなどの感性が育つものと考える といわれている ${ }^{19)}$ 。視能訓練士を目指す学生に とって、実習は身体的にも心理的にも緊張を強 いられるが、最も成長を期待できる実践学習で ある。したがって、臨地実習においては、学生 が患者や医療職者との関わりの中で、無意味に 緊張したり、自尊感情を損なわないようなサ ポートのあり方が望まれる。さらに、自己を尊 重できる人は、周囲の刺激や状況にむやみに動 摇したり、過度に不安を感じることもなく、他 者を尊重しながら現実を的確に認知し、適応し ようとする傾向があると思われる。こうした 能力は、視能矯正専攻学生が新しい臨床場面で の自己の能力を最大限に発揮しながら学習体験 を積み重ね、成長していく上で重要な要素とな り、久くことのできない資質であると考える。

本来、エゴグラムは生活習慣の変化や個人の 意識の持ち方によって柔軟に変化しうるもので ある。各自我状態の行動や対人パターンは肯定 的、否定的を併せもつため、一概に善悪を決め ることはできない。むしろ、エゴグラム調査後 の適切な個別の対応が必要になる ${ }^{20) 。 ~}$

学生は、専門職としての知識や判断等が未熟 な段階でN型であるが、今後、他人軸（NPと AC）だけでなく、自分軸（CPと FC）のバラ ンスがとれた自他肯定を示す視能矯正専攻学生 
の育成が望まれる。視能矯正専攻における態度 育成の教育では、1年次からもっている、医療 職に必要とされる「NP」を高值に保ち続ける と同時に、成人の「A」が高く機能するように 育つよう教育的配慮の必要性が示唆された。

\section{謝辞}

本研究は、平成 24 年度川崎医療福祉大学医療 福祉研究費の助成を受けて行われた。本研究を 遂行するにあたり、ご協力いただきました本学 感覚矯正学科視能矯正専攻の学生にお礼申し上 げます。また、実習受け入れ施設の実習指導者 の皆様に感謝申し上げます。

\section{参考文献}

1 ) 医療六法 (平成 25 年版) : 視能訓練士. $1621-$ 1645, 中央法規出版, 東京, 2013.

2 ) Stewart I, Joines V (深沢道子監訳) : TA TODAY - 最新 - 交流分析入門. 実務教育出 版, 東京, 1998.

3 ) Dusay J (新里里春訳) : エゴグラムーひと目 でわかる性格の自己診断. 創元社, 大阪, 2000.

4) 東京大学医学部心療内科 TEG研究会編: 新版 TEG II 解説とエゴグラム・パターン. 金子 書房, 東京, 2006.

5 ) 新里里春, 水野正憲, 桂 戴作, 杉田峰康: 交流 分析とエゴグラム.チーム医療, 東京, 2007.

6 ）三野節子, 金光義弘: 大学生の対人関係の基 本的構えと精神的健康との関係-交流分析に おけるエゴグラムの類型化を通して一. 川崎 医療福祉会誌 18: 418-484, 2009.

7 ）志渡晃一, 志水 幸, 蒲原 龍, 宮本雅央, 早川 明, 島谷綾郁, 他: 新入学生の対人関倸の基本 的構えと精神的・身体的自覚症状に関する研 究. 北海道医療大看福祉紀 14: 11-17, 2007.

8 ）末松弘行, 和田迪子, 野村 忍, 俵里英子: エゴ
グラム・パターン - TEG 東大式エゴグラム による性格分析一. 金子書房, 東京, 1990.

9 ) 難波哲子, 山下力, 田淵昭雄: 臨地実習指導 者評価と学生の「自己客観的評価」との相関 性. 日視会誌 38: 313-319, 2009.

10）稲光哲明, 筌 宗一: エゴグラムからみた看護 学生の成長過程 -1 年次と 4 年次の PCエゴグ ラムの比較 - . 交流分析研 32: 73-80, 2007.

11）武藤眞佐子: 看護短期大学学生の 3 年間の工 ゴグラムの変化. 北大医療技短大紀 12: 75-86, 1999.

12）真下りか: 看護学生の自己理解の一助として のエゴグラム. 交流分析研 28: 85-91, 2003.

13）三木園生, 行田智子, 石原輝美, 生方尚絵、中 嶋 彩: 看護学生の自我状態に関する調查 -1 年次と 3 年次の比較 - . 日看会論集 看教育 32: 92-94, 2001.

14）梅津靖江, 吉岡伸一: 看護学生と看護職の思 いやり行動と自我状態の比較. 米子医誌 62 : 91-102, 2011.

15）武藤真佐子: エゴグラムからみた看護者の成 熟性の特徵. 第26回日看会論集 看管理: 3033, 1995.

16）任 和子, 豊田久美子, 中井義勝, 他: エゴグラ ムからみた看護学生の自我状態の変化. 京大 医療技短大紀 健人間 9: 73-78, 1997.

17）桂 戴作, 杉田峰康, 白井幸子: 交流分析入門, 99-108, チーム医療, 東京, 1996.

18）稲葉佳江, 丸山知子: 看護学生の性格特性と 自我状態の変化. 交流分析研 14: 9-16, 1989.

19）白鳥さつき, 佐藤公美子, 比江島欣慎: 看護学 生・医学生の職業適応と自我状態に関する研 究. 医教育 35: 235-244, 2004.

20）中川幸子, 森 恵美: 看護大学生のエゴグラム パターンの特徵一変化群と無変化群の比較一. 日赤看大紀 7: 44-53, 1993. 